Заблоцький Володимир Валентинович доктор наук 3 державного управління, професор, професор кафедри публічної служби та управління навчальними й соціальними закладами ДЗ „Луганський національний університет імені Тараса Шевченка', пл. Гоголя 1, м. Старобільськ, 92703 тел.: (050) 591-86-41, e-mail: zablotskiivv@gmail.com, https://orcid.org/00000003-1032-8993

\title{
ЕТНОНАЦІОНАЛЬНІ АСПЕКТИ АДМІНІСТРАТИВНО- ТЕРИТОРІАЛЬНОЇ РЕФОРМИ В УКРАЇНІ НА РЕГІОНАЛЬНОМУ ТА МІСЦЕВОМУ РІВНЯХ
}

Анотація. В дослідженні розглянуто етнонаціональні аспекти реалізації адміністративно-територіальної реформи та процесу децентралізації в Україні. Визначено сутність етнонаціональної політики, ііі спрямованість та мета. Проаналізовано нормативно-правову базу, щодо впровадження державної етнонаціональної політики в процес формування об'єднаних територіальних громад у місцях компактного проживання національних меншин. При розробці та реалізації етнонаціональної політики не тільки на державному але й регіональному і місцевому рівнях потрібно враховувати історичні, етнічні, географічні, економічні, національно-культурні, релігійні, демографічні, міграційні особливості, а в деяких випадках і міжнародні зв'язки та відносини. Це суттєво вплине на практичну діяльність органів публічної влади, створить реальну можливість національним меншинам реалізувати свої права в економічному, освітньому, культурному просторі та приймати активну участь у державотворчих процесах, що $€$ умовою гармонізації міжетнічних відносин у державі. Для багатонаціональної держави головним змістом етнонаціональної політики є збереження балансу інтересів національних і етнічних груп 3 інтересами держави та кожного громадянина незалежно від того, проживає він на території держави чи за іiі кордонами. Етнонаціональна політика, як складова внутрішньої політики забезпечує стабільність країни та попереджає виникнення проявів націоналізму та сепаратизму. Історичний досвід свідчить, що в країнах 3 тоталітарним або авторитарним режимами неминуче виникають проблеми у відносинах, як в середині того чи іншого етносу, так і між етнічними групами, що призводить до етнічних конфліктів, хаосу та насильства в суспільстві. У світі накопичений значний досвід вирішення етнічних проблем - від конфліктного до консенсусного, тому для успішної розробки та реалізації державної етнонаціональної політики в Україні необхідно дослідити найбільш цікаві практики країн Центральної Європи, так як цей досвід може бути корисним при доопрацюванні національно-культурної та етнонаціональної політики нашої держави, створення надійної системи 
національної безпеки.

Ключові слова: етнонаціональна політика, адміністративнотериторіальна реформа, децентралізація, національні меншини, міжетнічні взаємовідносини, об'єднана територіальна громада, громадянське суспільство, націоналізм, національні інтереси.

Zablotskyi Volodymyr Valentynovych Doctor of Science in State Administration Professor, Professor of the Department of Service and Management of Educational and social Institutions of State Institution ,Luhansk Taras Shevchenko National University”, Gogol Square 1, Starobilsk, tel.: (050) 591-8641, e-mail: zablotskiivv@gmail.com, https://orcid.org/0000-0003-1032-8993

\section{ETHNO-NATIONAL ASPECTS OF ADMINISTRATIVE AND TERRITORIAL REFORM IN UKRAINE AT LOCAL LEVEL}

Abstract. Ethno-national aspects of realization of administrative and territorial reform and process of decentralization in Ukraine are considered in the research. The essence of ethno-national policy, its orientation and aim are specified. It is taken into consideration historic, ethnic, geographic, economic, culture, religious, demographic, migration specifics, and in some cases international relationships during the realization and implementation of the national politic at both the state and local level. All this will influence a practical activity of public authorities, will create a possibility for national minorities to exercise their rights within economic, education, and culture area and to take part in state building processes that are a condition of a harmonization of an inter-ethnic relationships in the country. The main maintenance of ethno-national politic for a multinational state is to keep a balance of interests between national and ethnic groups including an interest of the State and each citizen independently where he or she lives ether into the State or out of it. Ethnic politic is a part of a domestic policy that provides a stability of the State and prevents an appearance of nationalism and separatism. The historic experience shows that there is a problem regarding relationships in one or another ethos and among ethnic groups in country with totalitarian and authoritarian regimes. All this leads to ethnic conflicts, chaos and violence in society. There is an accumulated experience of resolving ethnic conflicts in the World such as conflict, consensual, and e.t.c. In order to develop and implement the State Ethno-national politic in Ukraine it is necessary to explore a successful experience in countries of the Central Europe. Because such an experience will be useful during revision of national-culture and ethnic- national politics of our country and creation of the reliable national security system. It is analyzed normative and legal base in relation to introduction of public ethnonational policy in the process of forming of united territorial communities in the area of densely habitation of national minorities, practical activity of public authorities, experience of Central European countries in development of questions of ethno-national policy and creation of the system of safety, it is exposed activity of international organizations on the protection of rights of national minorities. 
Keywords: ethno-national policy, administrative and territorial reform, decentralization, national minorities, interethnic mutual relations, united territorial community, civil society, nationalism, national interests.

Постановка проблеми. Україна на завершальному етапі докорінного реформування системи публічного управління. Цей процес торкнувся усіх гілок представницької та виконавчої влади, місцевого самоврядування. Реформа змінила адміністративний поділ держави. Частина громад була сформована у місцях компактного проживання національних меншин. Тому дуже важливо, щоб у цьому складному, багатогранному процесі не були порушені основи нашої державної етнонаціональної політики. Аналіз нормативно-правової бази показав, що $\epsilon$ прогалини у вітчизняному законодавстві, які треба доопрацювати та більш чітко визначити повноваження гілок публічної влади в Україні на регіональному та місцевому рівнях. Потребує доопрацювання законодавство про національні меншини. Це важливо, так як Україна багатонаціональна держава і гармонізація міжнаціональних та міжетнічних взаємовідносин $є$ пріоритетом у формуванні та реалізації національної політики. Аналіз показав, що є деякі прогалини не тільки в законодавстві але й в інформаційній політиці та залишається кадрова проблема на рівні середньої ланки керівників та виконавців. Ці проблеми треба вирішувати, враховуючи як вітчизняний досвід, так і досвід країн Центральної Свропи.

Аналіз останніх досліджень і публікацій. Проблема забезпечення гармонізації міжнаціональних та міжетнічних відносин була представлена в роботах Е.Мустафієвой [1], Ю. Куца[2], В.Овчарова[3], О.Куца, В.Заблоцького[4], Є.Кіма[5], Ю.Гамберса[6]. Але, в той же час дуже мало досліджень, присвячених практичній реалізації основних положень адміністративно-територіальної реформи і відповідність цього процесу етнонаціональної та міжнаціональної політики України. Реформа висвітлила деякі проблеми в нормативно-правовій базі, які необхідно доопрацювати у відповідності 3 вимогами часу. В цьому напряму працюють науковці Інституту права Верховної Ради України, Академії державного управління при Президентові України та ін. Вже підготовлені проекти законів „Про місцеві державні адміністрації”, „Про місцеве самоврядування”, „Про національні меншини”, „Про префекта".

Мета статті $є$ дослідження загальних тенденцій процесу створення об'єднаних територіальних громад, формування органів представницької і виконавчої влади в місцях компактного проживання національних меншин та відповідність цих процесів основним засадам етнонаціональної політики України.

Виклад основного матеріалу. Становлення Української держави відбувається паралельно із складним процесом подолання системи цінностей, яка залишилася у спадок від Радянського Союзу. Ринкові відносини, демократичний устрій, розвиток інститутів громадянського суспільства, європейський та євроатлантичний вектор розвитку, які прийшли на зміну 
моноцефальної системі управління - це був дуже складний крок, перш за все, в світогляді політиків, управлінців, мільйонів пересічних громадян. Той шлях, який більшість демократичних країн проходило за століття, Україна подолала за майже за тридцять років. Але щоб вийти на європейські соціальні та економічні стандарти, треба ще подолати багато проблем. Одна 3 них - це побудова європейської моделі етнонаціональної політики на базі національних культур, історичних традицій, ментальності національностей, які проживають на території України. Можливо те, що держава практично не мала досвіду розв'язання етнонаціональних проблем, призвело до того, що у деяких регіонах на заході та сході країни у населення залишаються відголоски незбалансованості традицій, культур, у тому числі і культури політичної. Внаслідок цього, так і не вдалося подолати ,центробіжні”, настрої. Вирішити ці проблеми можливо тільки створивши науково обгрунтовану, узгоджену 3 суспільством, закріплену в законодавстві національну, об’єднавчу ідею, мета якої - формування суспільства, у якому гармонійно розвиватимуться всі етноси, етнічні групи, а етнонаціональна політика буде засобом духовного, соціального, економічного розвитку української нації [1]. Таким чином, етнонаціональну політику держави можна визначити, як систему концептуальних програм i організаційних заходів у сфері етносоціального, етнокультурного та етнополітичного розвитку суспільства [2]. Етнонаціональна політика держави на сучасному етапі має передбачати виконання широкого комплексу завдань у різних сферах життя суспільства. Так, в економічній i соціальніх сферах держава повинна створити умови для розвитку інфраструктури територій компактного проживання національних меншин, допомогти залученню як зовнішніх так i внутрішніх інвестицій, розвивати виробництво, створювати додаткові робочі місця, розвивати структуру соціальних, культурно-освітніх послуг. Це суттєво вплине на етнодемографічні та міграційні процеси. Перелічені заходи допоможуть об’єднаній територіальній громаді стати спроможною та створити умови для життєдіяльності населення цієї території. Якщо розглянути правовий, політичний, духовний аспекти реалізації етнополітики на державному та регіональному рівнях, то, на наш погляд, треба серйозно зосередитися на доопрацюванні існуючої нормативно-правової бази, яка регулює міжнаціональні та міжетнічні процеси. Практика виявила недосконалість одних законодавчих актів та необхідність створення інших, які повинні регулювати правові та політичні умови розвитку територій компактного проживання національних меншин, а також стимулювати їх активну участь у державотворчих процесах по подальшому розвитку інститутів громадянського суспільства задля створення атмосфери взаєморозуміння і толерантності, досягнення загальнонаціональної злагоди і миру, протидія поширенню ідеології національної винятковості, шовінізму, ксенофобії [3]. Етнонаціональна політика має, як перспективні аспекти, тобто стратегічні, так і проблеми, які треба вирішувати сьогодні. Це означає, що процес розробки політики чи зовнішньої, внутрішньої чи регіональної процес дуже складний та довготривалий, тому треба мати достатньо чіткі 
уявлення про ситуацію не тільки в країні загалом, але й у кожному регіоні окремо. Вирішення проблеми співвідношення прав нації, громадянина та держави - основа національного відродження, стрижнем якого має бути загальнодержавна ідея, яка повинна відповідати принципам національної політики: повага до прав людини та основних свобод, у тому числі національних, незалежно від статі, віри, соціального становища та регіону проживання; рівні права етносів за різних форм їхнього самовизначення, 3 обов'язковою умовою збереження державності; рівні права і відповідальність районів та областей перед державою; багатонаціональна єдність держави, iї етносів та громадян; розвиток багатонаціонального українського суспільства шляхом діалогу, відмова від застосування сили; державна підтримка етносів, збереження їх культури, мови, традицій, середовища проживання; створення міжнародних гарантій захисту прав та свобод українців в іноземних державах [1].

Етнонаціональна політика $\epsilon$ складовою внутрішньої політики, яка забезпечує національну безпеку в сфері міжетнічних відносин і внутрішню стабільність країни та охоплює проблеми етнічної регіональної політики, різноманітні чинники міжетнічних та міжнародних відносин. Цей аспект державної етнонаціональної політики має деякі ризики, таки як: федералістські та регіональні настрої; етнонаціоналістичні і сепаратистські рухи; зовнішні чинники впливу на державу. Для багатонаціональної держави, якою є Україна, головним змістом етнонаціональної політики $є$ збереження балансу інтересів національних і етнічних груп 3 інтересами держави та кожного громадянина, незалежно від того, проживає він на території держави чи за їі кордонами. Це важливо, тому що в національній політиці дуже тонка лінія розмежування між поняттям „національні інтереси' і „націоналізм', Якщо ми відстоюємо національні інтереси, то це інтереси держави i всіх ऑii громадян незалежно від національності, віросповідання, політичних поглядів. У той же час, це інтереси всіх національних меншин або етнічних груп, без винятку, які відстоюють своє право на національну ідентичність : культуру, традиції, мову, політичні права [4]. При цьому вони залишаються громадянами держави. Націоналізм - це завжди намагання забезпечити виключне право своєї нації чи етнічної групи на панівне становище у державі або серед інших держав i, як правило, за рахунок інших народів вирішити свої економічні, політичні, соціальні проблеми. Практика показала, що завжди знаходяться політики або політичні сили, які на націоналістичних настроях вирішують або вузько групові, або особисті проблеми. І це створює загрозу національній безпеці та руйнує державотворчі процеси. Тому, при розробці та реалізації етнонаціональної політики не тільки на державному але й на регіональному рівні потрібно враховувати історичні, етнічні, географічні, економічні, національно-культурні, релігійні, демографічні, міграційні особливості, а в деяких випадках і міжнародні зв'язки та відносини. Все вище означене, треба обов'язково враховувати при реалізації адміністративнотериторіальної реформи, як при визначенні адміністративних кордонів об'єднаних територіальних громад, так і в процесі формування органів 
публічної влади на регіональному та місцевому рівнях. Так, прикладом достатньо гармонійно побудованих міжетнічних відносин може бути Одеська область, на території якої проживають сто тридцять шість національностей. 3 них достатньо компактним проживанням у межах шести об’єднаних територіальних громад та населених пунктів характеризуються угорці, болгари, молдовани, румуни, поляки, гагаузи, албанці та ін. Такі національні меншини області, як болгари, молдовани, гагаузи, албанці становлять переважну більшість громадян України цих національностей: болгари - 74,0\% (150,7тис.); гагаузи - 87,5\% (27,6тис.); албанці - 57,6\% (1,9тис.). Частина молдавської спільноти Одещини становить 48,1\% (123,8тис) від загальної кількості українських молдован, але є найчисельнішою в межах однієї області [7]. Але в ході реалізації реформи виявилися деякі проблеми, які були пов'язані з тим, що розроблені проекти планів формування територіальних громад не завжди отримали належну підтримки в регіонах, де компактна проживають національні меншини на рівні громад. До причин, що призвели до такої ситуації, можна віднести як недоліки в організації самого процесу об'єднання громад, тобто планування об’єднання без належного узгодження 3 місцевими громадами, відсутність широкого громадського обговорення i переконливого обгрунтування доцільності конфігурації об'єднання в одну громаду запропонованих територіальних громад, так i неврахування етнонаціональної та етнолінгвістичної структури населення адміністративних одиниць, географії розселення національних меншин, демографічних характеристик населених пунктів, геополітичного чинника. Така ситуація стала можливою тому, що посадові особи, причетні до організації об'єднувального процесу, виявилися недостатньо ознайомлені 3 нормативно-правовою базою 3 питань регулювання міжнаціональних відносин та етнонаціонального розвитку. Також виявилися певні прогалини в нормативних документах, які регламентують процес децентралізації, а також відсутність відповідного інформаційного супроводу. Треба зазначити, що 3 етнонаціональною політикою держави має бути узгоджена політика в інших сферах життя суспільства, наприклад, в адміністративній. Так, починаючи 32014 року, ключовим напрямом адміністративно-територіальної реформи $\epsilon$ децентралізація та реалізація ключового принципу Європейської хартії місцевого самоврядування - субсидіарності. У світі накопичений значний досвід вирішення етнічних проблем - від конфліктного до консенсусного. Найбільший шанс вийти 3 кризової ситуації та отримати перспективу стабільного розвитку мають етнічні об'єднання, яким належить певна самостійність у формуванні власної системи самоврядування. Воно $є$ основою демократичного суспільства, тому надання широких повноважень самоврядним структурам сприятиме розвитку самобутності i культури громад. Так, в південних регіонах компактного проживання національних меншин, де питання етнонаціональної політики розглядались на правовій основі, міжетнічних конфліктів практично не було. Прикладом може бути Одеська область. Більш складна ситуація виникла у західних областях, 
наприклад у Закарпатський області, де достатньо сильно відчувався вплив зовнішнього фактору. Треба зазначити, що діюче законодавство в Україні містить ряд норм щодо врахування поліетнічного характеру населення в адміністративно-територіальному устрої і організації влади. Так, у статті 119 Конституції України закріплено право місцевих державних адміністрацій на відповідній території забезпечувати у місцях компактного проживання корінних народів i національних меншин виконання державних та регіональних програм, їх національно-культурного розвитку. У статті 132 Конституції України зазначено, що територіальний устрій України грунтується на засадах єдності та цілісності державної території, поєднання централізації й децентралізації у здійсненні державної влади, збалансованості і соціально-економічного розвитку регіонів з урахуванням їх історичних, економічних, екологічних, географічних i демографічних особливостей, етнічних і культурних традицій [8]. У Законі України „,ро місцеві державні адміністрації' закріплене положення про те, що місцеві державні адміністрації, в межах відповідної адміністративно-територіальної одиниці, забезпечують виконання законодавства щодо національних меншин, мають взаємодіяти 3 відповідними об'єднаннями громадян із зазначених питань [9]. Відповідно до Закону України „Про місцеве самоврядування в Україні,', до компетенції виконавчих органів сільських, селищних, міських рад належить забезпечення в межах території, на який поширена регіональна мова, надання освіти цією регіональною мовою або мовою національних меншин [10].

На особливу увагу заслуговують норми Закону України „Про добровільне об'єднання територіальних громад’, які полягають у тому, що при прийнятті рішень, щодо добровільного об'єднання територіальних, беруться до уваги історичні, природні, етнічні, культурні та інші чинники, що впливають на соціально-економічний розвиток об'єднаної територіальної громади. При цьому, слід звернути увагу, що стаття 4 Закону України „Про добровільне об'єднання територіальних громад', не в повному обсязі відображає норму статті 132 Конституції України. Ця стаття не називає принцип „врахування багатокультурності”, а відсилає до Конституції України (конституційності та законності). Більш того, якщо відповідно Конституції України, повинно бути враховано історичні, етнічні, культурні традиції, то в Законі України лише ,беруться до уваги' історичні, етнічні культурні та інші чинники, за умови, якщо буде визнано, що вони впливають на соціально-економічний розвиток об’єднаної територіальної громади $[8,11]$.

Цікавим є приклад Чернівецької області, де проживають представники сімидесяти національностей. Це одна з найменших областей України, але на ii території сконцентровано багато етнокультурних особливостей. Треба зазначити, що місцеві органи державної влади та місцевого самоврядування поставилися з розумінням до етнонаціональних проблем. Адміністративними центрами шести об’єднаних територіальних громад стали населенні пункти, де компактна проживає румуномовне населення. А це $20 \%$ від загальної 
чисельності адміністративних центрів громад області [12].

Але $\epsilon$ й приклади, коли між деякими селами історично склалися специфічні стосунки, не зважати на які в подальшому не можна, так само, як i не враховувати релігійну ситуацію на окремих територіях. У політизованому суспільстві завжди знайдуться охочі спекулювати на цьому питанні. І це один з ризиків адміністративно-територіальної реформи.

Треба зазначити, що Закон України „Про національні меншини в Україні" не визначає механізмів представництва національних меншин у місцевому самоврядуванні, їхньої участі в управлінні на територіях компактного проживання, а також у визначенні обсягів, розподілі та контролю за формуванням бюджету та використанням бюджетних коштів [13] i це, на наш погляд, потребує доопрацювання. Потребують також доопрацювання Закони України ,, Про місцеві державні адміністрації’, „,ро місцеве самоврядування в Україні', „Про добровільне об'єднання територіальних громад', Крім того потребують нової редакції Постанови Кабінету Міністрів України „Про співробітництво територіальних громад” від 16 березня 2016 року, „Деякі питання надання субвенції з державного бюджету місцевим бюджетам на формування інфраструктури об'єднаних територіальних громад” від 8 травня 2015 року, „Про затвердження Методики формування спроможних територіальних громад' та ін. Тобто нормативно-правова база напрацьована але ii треба вдосконалювати та реалізовувати при здійсненні практичних кроків у розбудові нашої держави.

Відтак, головним чинником гармонізації міжетнічних відносин $\epsilon$ створення правової демократичної держави. Практика свідчить, що за тоталітарних та авторитарних режимів неминуче виникає дисгармонія у відносинах, як всередині того чи іншого етносу, так і між етнічними групами, що призводить до етнічних конфліктів, хаоса та насильства в суспільстві. Тому для успішної розробки та реалізації державної етнонаціональної політики в Україні необхідно дослідити практики зарубіжних країн, так як ïx досвід може бути використаний при доопрацюванні національнокультурної та етнонаціональної політики нашої держави. Як приклад, розглянемо етнополітику країн Центральної Європи. Конфліктогенність у цьому регіоні зумовлена різними причинами: нерівномірністю соціальнополітичного та економічного розвитку, диференціацією у доступі до ресурсів та соціальних можливостей, намагання розв'язати різні проблеми за рахунок інших етносів. Більш того, спроби етнічної асиміляції неодноразово провокували загострення етнічних конфліктів. Таким чином, взаємне бажання створити структуру, яка буде спроможна забезпечити реалізацію центрально-європейських інтересів 3 урахуванням національних прагнень польського, угорського, чеського та словацького народів, стимулювало рішення в угорському місті Вишеград підписати ,Декларацію про співробітництво Чеської і Словацької Федеративної Республіки, Республіки Польща і Угорської Республіки на шляху європейської інтеграції', У документі були зафіксовані спільні завдання, які вирішували центральноєвропейські постсоціалістичні країни на перехідному етапі та 
заради ефективності цього процесу домовилися про повне відновлення державного суверенітету, демократії і свободи, а також ліквідацію всіх суспільних, економічних i культурно-духовних залишків тоталітарної системи, розбудови парламентської демократії, інститутів громадянського суспільства, створення розвинутої ринкової економіки, інтегрованої до європейської політичної, економічної, правової системи та безпеки [5]. Треба відзначити, що на етапі становлення традицій співробітництва, пріоритетне значення мав національний рівень етнополітичного менеджменту, тобто розгалуженої структури інститутів держави, базовим завданням яких $\epsilon$ регулювання процесів етнонаціональної сфери життя суспільства. Він трансформувався, по мірі запровадження європейських норм захисту національних меншин, у національне законодавство Польщі, Словаччини, Чехії, Угорщини. Визначальний вплив на формування національного рівня етнополітичного менеджменту у країнах Вишеградської групи мали європейські структури. Це пов’язано, перш за все, з тим, що на початку 90-х років XX століття Свропейський Союз опинився під тиском етнополітичних конфліктів на Балканах. Тому, у той період, стабілізація політична, економічна, соціальна, міжнародна залежала від подолання міжнаціональних та міжетнічних конфліктів у Центральній Європі і були принципово важливим чинником для прогресу європейської інтеграції. Структури Євросоюзу та Ради Європи зробили все можливе, щоб послідовно запроваджувати у політичну культуру країн Вишеградської групи норми толерантності. Отже, етнополітичні проблеми в процесі демократизації країн Вишеградської групи вирішувались під посиленим впливом європейського інтеграційного процесу. Це, на наш погляд, проявлялось у тому, що наднаціональні підходи до етнонаціональної політики групувались на розумінні того, що на зміну моделі національній державності, фундаментом якої $\epsilon$ титульна нація, приходить модель громадянської держави, яка заснована на правових засадах громадянства, тобто незалежного від етнічної ідентичності [14]. Демократичне самовизначення держави можливе тільки тоді, коли народ певної держави перетвориться на націю громадян цієї держави, котрі самі візьмуть у руки свою політичну долю [6,с.75].

Треба зазначити, що після вступу країн Вишеградської групи до Європейського Союзу, суттєве значення набуло визнання офіційними мовами Євросоюзу усіх національних мов держав членів СС. В економічній сфері нівелювання міжетнічних протиріч стало можливим завдяки спільному економічному простору. Взагалі, якщо сьогодні розглядати проблеми міжнаціональних і міжетнічних взаємовідносин, то треба констатувати, що в умовах глобалізації, яка проявляється в економічних, політичних, культурноінформаційних перетвореннях, а також глибоких соціальних трансформаціях у світі, ставлення до національних меншин стає індикатором спроможності певної держави адаптуватися до вимог часу. С другого боку, розвиток системи місцевого самоврядування створює, а це тенденція часу у світі, реальну можливість етнічним групам у місцях компактного проживання реалізувати свої права в економічному, освітньому, культурному просторі та 
приймати активну участь в представницьких і виконавчих органах публічної влади. Все це створює реальні умови для гармонізації міжетнічних взаємовідносин та подальшої розбудови державотворчих процесів.

Висновки. В сучасних умовах дослідження різних аспектів реалізації прав етнонаціональних меншин у країнах світу набуває важливого значення. Це питання $\epsilon$ дуже актуальним для України. Забезпечити права етнонаціональних меншин можливо за умови ефективної взаємодії міжнародного і національного права. Відсутність такої правової взаємодії і традицій, ігнорування принципів етнонаціональної політики, недосконалість iii правового забезпечення може призвести до суттєвого погіршення ситуації 3 етнічними групами не лише в одній країні, а й привести до міжнародного загострення у певних регіонах. Гармонійні міжнаціональні та міжетнічні взаємовідносини - це шлях до поступового розвитку цивілізації і цей шлях людство повинно пройти разом.

\section{Лimepamypa:}

1. Мустафієва Е. Принципи об’єднання територіальних громад у місцях компактного проживання національних меншин в умовах децентралізації як складова частина етнонаціональної політики в Україні/Е.Мустафієва// Збірник наукових праць „Державне управління та місцеве самоврядування", Дніпропетровський регіональний інститут державного управління Національної академії державного управління при Президентові України, 2018, вип.№1(36), с. 24-25.

2. Куц Ю.О. Етнонаціональна політика України - головний напрям управління етнонаціональною сферою / Ю.О.Куц //Вісн. Харків. Національний університет внутрішніх справ. - 2000. - №12(1). - с. 256 - 260.

3. Овчаренко В. Етнополітика в сучасній Україні: проблеми формування законодавчої бази / В.Овчаренко//Етнічна історія народів Європи. - 2013. - Вип. №. - 39. c. $118-123$.

4. Куць О.М., Заблоцький В.В. Мовна політика України: аналіз та впровадження (етнополітологічний аспект) /О.М.Куць, В.В.Заблоцький// Харківський національний університет іменіВ.Н.Каразіна.,Харків 2007 р., с. 17-22

5. Кім Є. Європа у пошуках нової ідентичності: інституалізація процесів інтеграції країн Центрально-Східної Свропи / Є.Кім //Нова політика. - 1998. - №3. - с.3-22.

6. Гамберс Ю. Постнаціональна констеляція /Ю.Гамберс// Львів, 2010. с.4-5.

7. Розподіл населення України за рідною мовою, за національністю в розрізі адміністративних одиниць. Режим доступу:http://2001/ ukrcensus.gov.ua/results/nationality _poputation.

8. Конституція України. Відомості Верховної Ради України, 1996, №30, ст.141. Режим доступу: http://zakon.rada.gov.ua/laws/254/96-вр\#Text

9. Закон України „Про місцеві державні адміністрації’. Відомості Верховної Ради України, 1999, №20-21, ст. 190. Режим доступу: http:// zakon.rada.gov.ua / laws /show /586-14

10. Закон України „Про місцеве самоврядування в Україні”. Відомості Верховної Ради України, 1997, №24, ст.170. Режим доступу: http: //zakon.rada.gov.ua/law /show/280/97-вр.

11.. Закон України „Про добровільне об'єднання територіальних громад” від 5 лютого 2015 року №157-VIII. - Режим доступу:http://zakon.rada.gov.ua /laws / show/157-19 .

12. Заставецька О.В., Заставецький Б.У., Ткач Д.В. Географія населення України / О.В.Заставецька, Б.У.Заставецький, Д.В.Ткач// Навчальний посібник, Тернопіль., 2007.

13. Закон України „Про національні меншини в Україні’’. Відомості Верховної Ради 
України, 1992, №36, ст. 529. Режим доступу:http://zakon.rada.gov.ua/laws/2494 - 12\# Text

14. Етнічні меншини Східної та Центральної Європи: компаративний аналіз становища та перспектив розвитку /За ред. В.Свтуха// - К., 1994. - 207c.

\section{References:}

1. Mustafiieva, E. (2018). Pryntsypy obiednannia terytorialnykh hromad u mistsiakh kompaktnoho prozhyvannia natsionalnykh menshyn $\mathrm{v}$ umovakh detsentralizatsii yak skladova chastyna etnonatsionalnoi polityky $\mathrm{v}$ Ukraini [Principles of unification of territorial communities in places of compact residence of national minorities in decentralization as an integral part of ethno-national policy in Ukraine]. Derzhavne upravlinnia ta mistseve samovriaduvannia Public administration and local government, 1(36), 24-25 [in Ukrainian].

2. Kuts, Yu.O. (2000). Etnonatsionalna polityka Ukrainy - holovnyi napriam upravlinnia etnonatsionalnoiu sferoiu [Ethnonational policy of Ukraine - the main direction of management of ethnonational sphere]. Visn. Kharkiv. Natsionalnyi universytet vnutrishnikh sprav - Visn. Kharkiv. National University of Internal Affairs, 12(1), 256-260 [in Ukrainian].

3. Ovcharenko, V. (2013). Etnopolityka v suchasnii Ukraini: problemy formuvannia zakonodavchoi bazy [Ethnopolitics in modern Ukraine: problems of formation of the legislative base]. Etnichna istoriia narodiv Yevropy - Ethnic history of the peoples of Europe, 39, 118-123 [in Ukrainian].

4. Kuts, O.M., Zablotskyi, V.V. (2007). Movna polityka Ukrainy: analiz ta vprovadzhennia (etnopolitolohichnyi aspekt) [Language policy of Ukraine: analysis and implementation (ethnopolitical aspect)]. Kharkiv: Kharkivskyi natsionalnyi universytet imeni V.N.Karazina [in Ukrainian].

5. Kim, Ye. (1998). Yevropa u poshukakh novoi identychnosti: instytualizatsiia protsesiv intehratsii krain Tsentralno-Skhidnoi Yevropy [Europe in search of a new identity: the institutionalization of integration processes in Central and Eastern Europe]. Nova polityka - New Policy, 3, 3-22 [in Ukrainian].

6. Hambers, Yu. (2010). Postnatsionalna konsteliatsiia [Postnational constellation]. Lviv [in Ukrainian].

7. Rozpodil naselennia Ukrainy za ridnoiu movoiu, za natsionalnistiu $\mathrm{v}$ rozrizi administratyvnykh odynyts [Distribution of the population of Ukraine by native language, by nationality in terms of administrative units]. 2001.ukrcensus.gov.ua. Retrieved from http://2001.ukrcensus.gov.ua/i/u/popul_adm_00.zip [in Ukrainian].

8. Konstytutsiia Ukrainy [Constitution of Ukraine]. (1996). Vidomosti Verkhovnoi Rady Ukrainy - Bulletin of the Verkhovna Rada of Ukraine, 30. Art. 141. Retrieved from http://zakon.rada.gov.ua/laws/254/96-vr\#Text [in Ukrainian].

9. Zakon Ukrainy "Pro mistsevi derzhavni administratsii" [Law of Ukraine "On Local State Administrations"]. (1999). Vidomosti Verkhovnoi Rady Ukrainy - Bulletin of the Verkhovna Rada of Ukraine, 20-21. Art. 190. Retrieved from http://zakon.rada.gov.ua/laws/show/586-14 [in Ukrainian].

10. Zakon Ukrainy "Pro mistseve samovriaduvannia v Ukraini" [Law of Ukraine "On Local Self-Government in Ukraine"]. (1997). Vidomosti Verkhovnoi Rady Ukrainy - Bulletin of the Verkhovna Rada of Ukraine, 24. Art. 170. Retrieved from http://zakon.rada.gov.ua/law /show/280/97-vr [in Ukrainian].

11. Zakon Ukrainy "Pro dobrovilne obiednannia terytorialnykh hromad" : vid 5 liutoho 2015 roku, № 157-VIII [Law of Ukraine "On Voluntary Association of Territorial Communities" of February 5, 2015 №157-VIII]. zakon.rada.gov.ua. Retrieved from http://zakon.rada.gov.ua/laws/show/157-19 [in Ukrainian].

12. Zastavetska, O.V., Zastavetskyi, B.U., Tkach, D.V. (2007). Heohrafiia naselennia Ukrainy [Geography of the population of Ukraine]. Ternopil [in Ukrainian].

13. Zakon Ukrainy "Pro natsionalni menshyny v Ukraini" [Law of Ukraine "On National 
Minorities in Ukraine"]. (1992). Vidomosti Verkhovnoi Rady Ukrainy - Bulletin of the Verkhovna Rada of Ukraine, 36. Art. 529. Retrieved from http://zakon.rada.gov.ua/laws/2494 12\# Text [in Ukrainian].

14. Yevtukh, V. (Eds.). (1994). Etnichni menshyny Skhidnoi ta Tsentralnoi Yevropy: komparatyvnyi analiz stanovyshcha ta perspektyv rozvytku [Ethnic minorities of Eastern and Central Europe: a comparative analysis of the situation and prospects for development]. Kyiv [in Ukrainian]. 